\title{
State Support for the Russian Economy Affected by Covid-19 Consequences (Legal Aspects)
}

\author{
A. A. Malinovsky ${ }^{1(凶)}$, D. M. Osina ${ }^{1}$, and E. N. Trikoz ${ }^{1,2}$ \\ 1 Moscow State Institute of International Relations, MGIMO University, \\ Moscow, Russia \\ Dr.malinovsky@yandex.ru, osina.dina@yandex.ru, \\ alena_trikoz@mail.ru \\ 2 Peoples' Friendship, University of Russia, RUDN University, Moscow, Russia
}

\begin{abstract}
Measures aimed at combating the coronavirus have already negatively affected the Russian economy. In the future, macroeconomic indicators will deteriorate. The study considers the analysis of relevant government measures to protect the Russian economy in the new realities of the pandemic. For the first time the team of authors (using the method of economic analysis of law) studied the regulatory and analytical material on supporting the Russian economy in the crisis. As a result of the study, the authors come to the following conclusions: 1) the Russian authorities promptly adopted a package of legislative acts to protect the Russian economy; 2) most government measures can potentially be effective and capable of supporting the Russian economy in the context of the coronavirus epidemic, however, it is too early to talk about the final effectiveness and sufficiency of these measures; 3 ) some measures, despite the fact that they will accumulate funds in the budget, could potentially have a negative effect on the Russian economy in the future.
\end{abstract}

Keywords: COVID-19 $\cdot$ Economic measures $\cdot$ Financial crisis $\cdot$ State support $\cdot$ Russian economy

\section{Introduction}

On December 31, 2019, the whole world became aware of the outbreak of a new coronavirus infection in the Chinese city of Wuhan. The Russian authorities promptly responded to the new challenges of the pandemic by developing a kind of "rulemaking vaccine" - a package of legislative acts providing for a set of measures to combat the economic consequences of the coronavirus. These measures were developed considering the views of business representatives, for example the Chamber of Commerce and Industry of Russia presented its proposals for supporting the business, including some e-commerce initiatives [4].

Give to him that asketh thee, and from him that would borrow of thee turn not thou away. (Sermon on the Mount).

(C) The Editor(s) (if applicable) and The Author(s), under exclusive license

to Springer Nature Switzerland AG 2021

S. I. Ashmarina et al. (Eds.): ENGINEERING ECONOMICS WEEK 2020, LNNS 139, pp. 283-287, 2021. 


\section{Methodology}

The basis of this study is an extensive regulatory and analytical material on the regulatory impact on the Russian economy in the pandemic. The source and empirical base are the appeal of V.V. Putin, the President of the Russian Federation, a package of federal anti-crisis laws and regulations [10].

\section{Results}

To coordinate the activities of executive authorities during the pandemic, in accordance with Decree of the Government of the Russian Federation No. 236 dated 05.03.2020, the Government Commission was formed to increase sustainable development of the Russian economy (hereinafter referred to as the Commission) and the regulation on it was approved [7]. One of the tasks of the Commission is to develop measures to support the real sector of the economy, including reducing costs for businesses and systemically important enterprises.

On 25.03.2020 V. V. Putin, the President of the Russian Federation, addressed the citizens of Russia, within the framework of which he announced a list of measures to support the Russian economy. On 29.03.2020 the list of instructions of the President of the Russian Federation based on the results of this appeal was published [8].

On 01.04.2020 V.V. Putin signed a package of federal laws to amend certain legislative acts of the Russian Federation to support the Russian economy, which were published and entered into force on the same day. On 02.04.2020 the President of the Russian Federation signed a decree on the extension of "non-working days" in Russia for the whole of April this year with the suspension of the work of companies, banks and enterprises regardless of their form of ownership, which caused additional concern of a few economists. According to estimates by analysts of the Center for Macroeconomic Analysis and Short-Term Forecasting, the direct instant effect of the "nonworking day regime" will be up to $20 \%$ of GDP losses, or almost 18 trillion rubles [12]. Now it is advisable to consider those measures that have been taken by the Russian authorities to support the Russian economy.

At the federal level, the Law came into force, according to which individual entrepreneurs whose average monthly income will decrease after March 1, 2020 by more than $30 \%$ due to the coronavirus are entitled to apply for the so-called credit holidays for up to 6 months, during which they cannot be charged fines and penalties, be foreclosed on collateral or mortgages etc. Federal Law dated 01.04.2020 introduced a new concept of "national guarantee system for supporting small and medium-sized enterprises", which means the system of providing entities with sureties and (or) independent guarantees for their obligations when accessing credit and other financial resources [6].

Other measures were promptly taken at the legislative level, e.g., a temporary moratorium on bankruptcy at the request of creditors was established, insurance contributions were reduced, rent payments were delayed (on municipal and state property), and tax, customs and other inspections of small and medium-sized enterprises (hereinafter referred to as SMEs) were suspended (from April 1 and until the end of 2020). 
The Law on the Protection and Promotion of Investment in the Russian Federation was signed, which established a ban on actions that worsen the conditions for doing business related to the implementation of private and public investment projects.

The system-wide measures to support the economy described in the Government's "Plan of Priority Measures" dated 17.03.2020 can be divided into three blocks: (1) financial and budgetary measures - create a financial reserve of up to 300 billion rubles; create a guarantee fund for the restructuring of company loans; expand measures to support the budgets of the Russian Federation, faced with a fall in tax revenues, by exempting regions from repayment of budget loans in 2020; accelerate state capital investments by simplifying procedures and reducing the composition of documents related to amendments to the federal targeted investment program; (2) preferential and security measures - not apply penalties; extend terms and price adjustments under state and municipal contracts in case of violation of obligations by the contractor due to the consequences of the coronavirus; inform residents about necessary actions in case of non-fulfillment (to prevent the occurrence of non-fulfillment) of the delivery (payment) of goods by foreign counterparties under foreign trade contracts and non-return of funds previously paid by residents if such non-fulfillment is caused by force majeure; give the Government of the Russian Federation the right to determine the procedures for obtaining a deferral (installment plan) for the payment of taxes, fees and contributions, including with regard to the procedure, grounds and deadlines for their submission, as well as the right to extend the deadline for submitting tax returns (calculations); (3) provide operational monitoring of the financial and economic state of backbone organizations of the Russian economy (over 600 companies) [1].

In addition to system-wide support measures, two separate blocks were identified: (4) measures to support SMEs, and (5) priority measures to support sectors of the economy that are at risk (loan borrowers; transport organizations; cultural and physical education and sports institutions; tour operators; leasing companies; construction industry). The same example was followed by some regional authorities [3]. In relation to the subjects in the so-called "Risk areas of the economy" there are the following measures: restructuring loans in connection with the spread of the coronavirus; providing financial support for transport organizations; subsidizing interest rates on loans to developers in the framework of project financing; supporting leasing companies, including their additional capitalization; paying partial compensation for losses to national sports federations; granting a deferral of tax payments (for 3 months); extending labor permits to foreign workers, etc.

\section{Discussion}

State support measures for SMEs are the following: grant a deferral on loans and all taxes, with the exception of VAT for the next 6 months, and for microenterprises - also provide additional deferrals on insurance contributions to social funds; decrease in half (up to $15 \%$ ) the amount of insurance contributions by the amount of the salary exceeding the minimum wage; introduce a moratorium on inspections of SMEs, including tax audits, with the exception of issues that pose risks to the life and health of citizens; expand the program for subsidizing the access of SMEs to borrowed funds; 
restructure loans of the borrower - a subject of SMEs; subsidy (up to $1 / 2$ the rate of the agreement, but no more than the key one) a part of the interest on loans of SMEs subjects to the postponement of the payment of interest without charging penalties to credit organizations; provide temporary postponement (or moratorium) on the payment of rental payments by subjects of SME-tenants of state or municipal property; provide coverage of preferential microloans by SMEs; expand the capabilities of SMEs to obtain soft loans in the absence of collateral; reduce requirements for securing contracts during public procurement from SMEs; not apply penalties, as well as extend terms and price adjustments in 2020 in case of violation of obligations by the contractor (within the framework of 223-FL) due to the consequences of the coronavirus [5].

In addition to the above, the President of the Russian Federation announced the following measures to support the Russian economy: ensure sustainable lending to the real sector, including the provision of state guarantees and subsidizing interest rates on loans; protect enterprises, that are in a difficult situation, from bankruptcy by introducing a moratorium on filing creditors' applications for bankruptcy of companies and collecting debts and fines for a period of 6 months; introduce a tax on interest income of $13 \%$ for citizens whose total amount of bank deposits or investments in debt securities exceeds 1 million rubles in 2021; increase withholding tax rate on dividends to $15 \%$ if they are remitted to foreign accounts in countries through which significant resources of Russian origin pass, and therefore the Government decided to review the network of bilateral double taxation agreements [10], starting with the Agreement with the Republic of Cyprus, Article 10 of which provides for the possibility of taxation of dividends at preferential rates of 5 and $10 \%$, provided that they are paid to a company that is a beneficial owner of such dividends and complies with the investment criterion [2]. On 27.03.2020 in pursuance of instructions of the President of the Russian Federation, the Commission identified 22 sectors of the economy that were most affected by the spread of the coronavirus, to provide priority targeted state support [9]. By Order of the Government of the Russian Federation No. 767-r of 28 March 20201.5 billion rubles were allocated from the reserve fund of the Government of the Russian Federation to the Federal Air Transport Agency to reimburse the costs incurred by air transport organizations due to the return of Russian citizens from foreign countries with Covid-19 epidemic [11].

\section{Conclusion}

As follows from the analysis, the Russian authorities are already taking measures to protect the Russian economy and support enterprises (organizations). The measures introduced are undoubtedly intended to alleviate the situation of business entities by mitigating as much as possible the negative consequences of the outflow of visitors and clients against the background of quarantine measures. However, several measures can be ambiguously construed. E.g., the introduction of the above-mentioned tax on interest on deposits does not directly contribute to improving the economic situation, since in fact the state will receive the first revenue from such a measure only in 2022 . At the same time, this measure will automatically reduce the attractiveness of deposits as an investment tool, which in fact does not contribute to the attraction of private funds 
by banks. A potential $15 \%$ withholding tax for dividends paid by Russian companies is fraught with a decrease in the attractiveness of Russian jurisdiction for potential investors, which may have a negative cumulative economic effect in the future. In general, the "freezing of the Russian economy" currently being legalized will have the following result - a certain part of SMEs will simply not survive this suspension and will not pay off their obligations. Restructuring of loans to companies and citizens affected by the coronavirus will lead to a significant deterioration in the quality of the loan portfolio of many large banks in Russia.

\section{References}

1. Adamchuk, O., Trifonova, P.: The government has 3 times increased the list of backbone companies. Vedomosti (2020). https://www.vedomosti.ru/economics/articles/2020/03/23/ 825894-pravitelstvo-raza-sistemoobrazuyuschih. Accessed 01 May 2020

2. Agreement between the government of the Russian Federation and the government of the Republic of Cyprus for the avoidance of double taxation with respect to taxes on income and capital (1998). http://www.consultant.ru/document/cons_doc_LAW_23908/. Accessed 01 May 2020

3. Decree of the Governor of the Pskov Region dated March 19, 2020 No. 33-UG "On priority measures to support small and medium-sized enterprises operating in economic sectors which are at risk in connection with the implementation of measures to counteract the spread of the new coronavirus infection in the Pskov Region (2019-nCoV)". https://rg.ru/2020/04/ 08/pskov-ukaz42-reg-dok.html. Accessed 01 May 2020

4. Economy and Life: RF CCI sent Mishustin a second package of proposals on business support (2020). https://www.eg-online.ru/news/417215/. Accessed 01 May 2020

5. Federal Law No. 223-FL of July 18, 2011 "On procurement of goods, works, services by certain types of legal entities”. http://base.garant.ru/12188083/. Accessed 01 May 2020

6. Federal Law No. 83-FL of 01.04.2020 "On amendments to the Federal Law "On the development of small and medium-sized enterprises in the Russian Federation" with a view to developing a national guarantee system for supporting small and medium-sized enterprises". http://base.garant.ru/73827394/. Accessed 01 May 2020

7. Government of the Russian Federation: government commission for improving the sustainability of the Russian economy (2019). http://government.ru/department/549/about. Accessed 01 May 2020

8. List of instructions based on the appeal of the President of the Russian Federation in connection with the spread of coronavirus infection in the country (2020). http://kremlin.ru/ events/president/news/63080. Accessed 01 May 2020

9. List of selected areas of activity most affected by the deterioration of the situation due to the spread of the new coronavirus infection to provide priority targeted support (2020). https:// www.economy.gov.ru/material/file/be6cf04db17a6caed6bfa9fd97684d7b/26032020.pdf. Accessed 01 May 2020

10. Official website of the President of Russia: meeting with members of the government of the Russian Federation (2020). http://kremlin.ru/events/president/news/63123. Accessed 01 May 2020

11. Order of the government of the Russian Federation No. 767-r of 28 March 2020. http:// government.ru/docs/39308/. Accessed 01 May 2020

12. Yastrebova, S., Mereminskaya, E.: Extension of non-working days threatens with reductions and bankruptcies. Vedomosti (2020). https://www.vedomosti.ru/economics/articles/2020/04/ 02/827003-sokrascheniyami-i-bankrotstvami. Accessed 01 May 2020 